\title{
Into the Woods: Analyzing Normative Evolution and the International Tropical Timber Organization
}

\section{Gerry Nagtzaam}

Senior Lecturer, Faculty of Law, Monash University, Clayton, Victoria, Australia

*Corresponding author: Dr. Gerry Nagtzaam, Senior Lecturer, Faculty of Law, Monash University, Clayton, Victoria, Australia, Tel: + 61 03 99053330; E-mail: gerry.nagtzaam@monash.edu

Received date: August 11, 2014, Accepted date: November 05, 2014, Published date: November 15, 2014

Copyright: (c) 2014 Nagtzaam G. This is an open-access article distributed under the terms of the Creative Commons Attribution License, which permits unrestricted use, distribution, and reproduction in any medium, provided the original author and source are credited.

\begin{abstract}
This article explores the attempts to create a global tropical timber regime and its underlying competing environmental norms of exploitation, conservation and preservation. It outlines a history of forestry exploitation over time and tracks the stilted development of a global tropical timber regime. It further examines the development of the International Tropical Timber Agreement and its concomitant Organisation. Legro's test of the robustness of a norm will be applied to the tropical timber regime to determine when and why, and through whose agency, normative change has not been effected within the International Tropical Timber Organisation where conservationist norms have failed to take root.
\end{abstract}

Keywords: Tropical timber; Norms; Exploitation; Conservation

\section{Introduction}

Currently, one can observe a mass extinction of biomass occurring that of the loss of irreplaceable tropical forests. The regime established to prevent such widespread exploitation and put in place effective environmental norms ${ }^{2}$ and management processes is widely considered a failure. This is primarily due to the fact that both producer and consumer timber states' economic interests are best served by allowing the harvesting of tropical timbers to continue virtually unabated at the expense of good environmental outcomes. While attempts have been made by various global actors including Environmental Non-Governmental Organisations (ENGOs), International Organisations (IOs) and concerned states to strengthen the environmental norms of the regime efforts, even with global support for improved environmental outcomes, efforts have come to naught.

The creation of the International Tropical Timber Agreement (ITTA) and its concomitant organisation, the International Tropical Timber Organisation (ITTO) have in many ways perversely exacerbated forest degradation rather than balance the competing economic and environmental issues as was promised. In part this is in consequence of a particularly effective veto coalition, compromising both producer and consumer states, that has stymied the entrenchment of higher order environmental values such as conservation and/or preservation mores [1-10].

Before critically examining the current tropical timber regime, it is necessary to define and understand the differing potential environmental norms of exploitation, conservation and preservationism that can underpin a biodiversity regime that will be scrutined here. These environmental concepts need to be clearly delineated to enable us to better chart the evolution of the regime or to explain the factors that have retarded its development. Inexplicably the concept of 'exploitation' as it pertains to the environment has received scant conceptual analysis from researchers. ${ }^{3}$ One of the few authors to do so is Taylor who, rather than defining exploitation per se, speaks of an exploitative attitude, where nature is seen as a repository of resources to be developed, used, and consumed for human ends." ${ }^{4}$ For the purposes of this paper, Taylor's work will be utilized and expanded to define environmental exploitation as the use of natural resources without consideration for the survivability of the resource, the overall ecosystem or the rights of future generations of humans [11-20].

Conservationists regard the nonhuman world as a resource,,$^{5}$ a reservoir of matter-energy to be altered by technology ${ }^{6}$. Rodman believes, errantly when it comes to tropical forests, that the norm of conservation has replaced, "the reckless exploitation of forests, wildlife, soils etc." with an, "ethical and legal requirement that 'natural

$1 \quad$ Regimes are best understood as, "sets of implicit or explicit principles, norms, rules and decision-making procedures around which actors' expectations converge in a given area of international relations." Stephen D. Krasner, International Regimes, Cornell Studies in Political Economy. (Ithaca: Cornell University Press, 1983), 2. It subsumes within it both formal governmental organizations (e.g. United Nation agencies) and regularized forms of policy coordination around a specific issue." Ian H. Rowlands, "Classical Theories of International Relations," in International Relations and Global Climate Change, ed. U. Luterbacher and D.F. Sprinz (2001), 55.

2 A norm is defined as: “...shared expectations about appropriate behaviour held by a collectivity of actors..."J.T. Checkel, "Norms, Institutions and National Identity in Contemporary Europe," International Studies Quarterly 43 (1999): 83.

3 Alan Wertheimer, Exploitation (Princeton, N.J.: Princeton University Press, 1996), 5.

4 Paul W. Taylor, Respect for Nature: A Theory of Environmental Ethics (Princeton, N.J.: Princeton University Press, 1989 ), 95.

5 Robyn Eckersley, Environmentalism and Political Theory: Toward an Ecocentric Approach (London: UCL Press, 1992$), 36$.

6 Max Oelschlaeger, Idea of Wilderness: From Prehistory to the Age of Ecology, New ed. (New Haven: Yale University Press, 1993$), 287$. 
resources' be used 'wisely', in the interests of humanity at large rather than in the interests of a mere few, and considered over the 'long run' rather than the short term." " A conservationist approach, sometimes referred to as "sustainability", ${ }^{8}$ is thus a utilitarian, anthropocentric perspective that seeks the greatest good for the greatest number of humans. Such conservation can be of renewable or non-renewable resources, providing there is a husbanding of the resource for use by both present and future human generations. ${ }^{9}$

The concept of preservation is defined by John Passmore as: “...the attempt to maintain in their present condition such areas of the earth's surface as do not yet bear the obvious marks of man's handiwork and to protect from the risk of extinction those species of living beings which man has not yet destroyed." Thus preservationists accord an intrinsic value to the non-human world, even if it conflicts with human interests differentiating it from conservationist thought. ${ }^{10}$

A second issue is that although descriptions and evaluations of norms in environmental literature are widespread, studies as to why and how actors adhere to particular norms and the rationale as to why they do so are rare. Even within the study of strategic norms, there has been little analysis examining the dynamics of norm articulation and internalisation within regimes and "...how [norms] can get started how a partial norm can be sustained and become well established and how one norm can displace another." ${ }^{11}$ As Jeffrey Legro points out:

The literature on norms has generally mis-specified their impact because of several conceptual and methodological biases...by concentrating on showing that norms "matter" analysts have given short shrift to the critical issues of which norms matter, the ways they matter, and how much they matter relative to other factors. ${ }^{12}$

Legro's work on normative analysis can go a long way towards remedying this deficiency. He posits two biases in this area that have skewed analysis [21-30]. One is an inability to perceive "norm robustness" as an independent variable for research purposes, separate from the effects generally attributed to the norm. ${ }^{13}$ Two, the plethora of work to date in the area have erroneously focused on norms perceived to have "worked" rather than ones that have "failed." As Legro maintains, "[w]hy norms did not emerge or were not consequential is as important as why they did or were." ${ }^{14}$ Examining a normative 'failure' may shed light on normative construction and normative evolution and the factors determining that bring about such a breakdown [31-40].

\section{Test of norm robustness}

Legro's research enables a critical analysis of normative evolution determining their relative robustness. He proposes a three-pronged test to enable determination of the strength of a particular norm utilizing three criteria: specificity, durability, and concordance ${ }^{15}$. A norm's strength can thus be judged on its specificity or "how precisely a norm distinguishes appropriate from inappropriate behavior." 16 Or alternatively, "how well guidelines for restraint and use are defined and understood." 17 This enables us to ask whether norms are overly complex and ill defined or simple and precise? To answer this question it is necessary to determine "....actors' understandings of the simplicity and clarity of the prohibition." 18 Determining such understandings can be aided by analysing the explication of norms in such documents as written conventions. A treaties' non-specific applied standard of behaviour allows for a wide range of behavioural possibilities that could be deemed appropriate but do not allow any accurate determination as to whether a norm has been violated. Such unspecified norms are not appropriate as a standard for gauging appropriate behaviour and thus should not be treated as an independent variable that can carries explanatory weight as to a norm's efficacy. ${ }^{19}$

Legro then proposes a test to determine a norm's durability by asking, "how long the rules have been in effect and how they weather challenges to their prohibitions." 20 Are violators of the norm penalized and if so, in what way are they punished? He cautions though that a violation of the norm should not be interpreted as meaning the norm has no validity. He gives the example of the norm of incest being durable despite repeated infractions of the taboo. Rather, the issue is whether the errant actors were punished or censured either by themselves or their society. ${ }^{21}$

Lastly, Legro scrutinizes the concept of concordance or commonality, ${ }^{22}$ or, "how widely accepted are the rules in diplomatic discussions and treaties (that is, the degree of intersubjective agreement)." ${ }^{23}$ Do states agree on the acceptance of the validity of a norm? Has the norm been internalized by the member-states so its

7 Hay, Main Currents in Western Environmental Thought, 31.

8 For the purposes of this paper, as is often done both by the ITTO and other actors and commentators, the terms "conservation" and "sustainability" will be utilized interchangeably.

9 Taylor, Respect for Nature: A Theory of Environmental Ethics, 298.

10 W. Godfrey-Smith, "The Rights of Non-Humans and Intrinsic Values," in Environmental Philosophy, ed. D.S. Mannison, M.A. McRobbie, and R. Routley (Canberra: Department of Philosophy, Research School of Social Science, Australian National University, 1980), 31.

11 Robert M. Axelrod, The Complexity of Cooperation: Agent-Based Models of Competition and Collaboration, Princeton Studies in Complexity (Princeton, NJ: Princeton University Press, 1997), 65.

12 J.W. Legro, "Which Norms Matter? Revisiting the 'Failure' of Internationalism," International Organization 51, no. 1 (1997): 31.

13 Ibid.: 33.

$14 \quad$ Ibid.: 34

15 Ibid

16 Henning Boekle, Volker Rittberger, and Wolfgang Wagner, "Norms and Foreign Policy: Constructivist Foreign Policy Theory,"

Tubingen Working Papers 34a (1999): 6.

17 Legro, "Which Norms Matter? Revisiting the 'Failure' of Internationalism," 34.

18 Ibid.

19 Boekle, Rittberger, and Wagner, "Norms and Foreign Policy: Constructivist Foreign Policy Theory," 7.

20 Legro, "Which Norms Matter? Revisiting the 'Failure' of Internationalism," 34.

21 Ibid.: 35 . 
veracity is not questioned ${ }^{24}$ Do states accept the validity of the norm? Do states put conditions on acceptance of the norm there by diminishing its efficacy? ${ }^{25}$ We can speak of a high degree of commonality if all actors accept a certain value-based expectation of behaviour, a middling degree if a majority of actors share the same expectation of behaviour, and low commonality if a minority ascribe to the proposed expectation of behaviour. ${ }^{26}$

For Legro, a norm should have at least a medium level of commonality before it can be stated with certainty to be exerting any influence on a particular states' behaviour. ${ }^{27}$ This is best carried out by critically evaluating the published records of domestic and international discussions, and this will be undertaken here in this paper. Thus Legro argues, “...that the clearer, more durable, and more widely endorsed a prescription is, the greater will be its impact" and consequently its robustness. ${ }^{28}$ The greater the level of commonality exhibited, the more robust the explanation proffered will be. The lower the commonality demonstrated the greater the likelihood that the expectation is not an independent variable but rather some other variable. A proper normative analysis must thus demonstrate: "that certain groups assert themselves over their rivals because of the norms they share." 29 Only then should it be considered that the examined norm is the explanatory variable [41-50].

This paper will take up the challenge issued by Legro and, using his test of norm robustness, seek to unpack the notion of normative competition and transformation within the global tropical timber regime. It will have a particular focus on attempts by various normative entrepreneurs to bring about the conditions to have the norm of conservation supplant the norm of exploitation as the guiding norm underpinning the ITTO (the norm of preservation has barely featured in ITTO discussions for reasons that will be made apparent). This article will examine the intense logging of tropical timber within various states, with particular emphasis on the Asia-Pacific region. It charts the extensive exploitation of tropical forests and the environmental impact of such degradation. It critically examines the attempts by concerned member-states of the International Tropical Timber Council (ITTC) and ENGOs to limit such destruction by the development of a tropical timber protection regime and evaluates the success of such measures. It focuses primarily, as suggested by Legro's analysis, on the negotiations to create the ITTA (and ITTO) and the discussions surrounding the ITTAs subsequent iterations as well as the failed efforts to implement programmes at the domestic level to better protect tropical forests.

Further, this paper explores the reasons for the failure of the positive environmental norms of conservation and preservation to supplant the dominant norm of exploitation underpinning the tropical timber regime. Here is a "hard case" of 'progressive normative failure" where the conservationist and preservationist arguments of the various ENGOs and concerned states have not been accepted and where exploitation continues to be the order of the day. Such an ongoing norm requires both a critical evaluation and explanation as a matter of urgency to alleviate the situation [51-60].

\section{Tropical Forest Deforestation}

When examining the issue of exploitation of tropical forests the first issue encountered is in accurately determining the ongoing rate of deforestation. No definitive answer can be given due to a variety of reasons including differing definitions of what constitutes deforestation; inaccuracies in methodologies to determine deforestation and an ongoing lacunae in data collection by individual states which have vested interests in not providing a complete accounting of their activities. ${ }^{30}$ However, an examination of the, admittedly imprecise current picture, can provide a limited understanding of the current situation which is sufficient to provide a casus belli for immediate action.

Despite awareness of the issue of deforestation and the global communities attempts to stem the tide, ongoing deforestation at the state level continues almost unabated, particularly in a number of South-east Asian countries. A Wetlands International Report puts the deforestation rate for all of Asia during the last five years at $2.8 \%{ }^{31}$ Since 1973 to 2009 the greater Mekong area lost almost a third of its forests with Vietnam and Thailand the worst offenders losing $43 \%$ of their forest cover the WWF estimates using satellite analysis. ${ }^{32} \mathrm{~A}$ report from the U.N.'s Economic and Social Commission for Asia and the Pacific in 2008 estimated that South-east Asia was losing 28,000 square kilometres of forest annually. ${ }^{33} \mathrm{~A} 2011$ study found that Borneo lost $12 \%$ of its forest or 5 million hectares between 2000 and $2010 .{ }^{34}$ Further, a Wetlands International Report has estimated that the

22 Commonality is generally defined as meaning "how many actors of a social system share a value-based expectation of behavior." Boekle, Rittberger, and Wagner, "Norms and Foreign Policy: Constructivist Foreign Policy Theory," 6.

23 Legro, "Which Norms Matter? Revisiting the 'Failure' of Internationalism," 35.

24 Internalization of a norm occurs when a norm has been so thoroughly accepted by actors that it can considered to be "taken for granted". Risse, "'Lets Argue!": Communicative Action in World Politics," 6.

25 Ibid.

26 Boekle, Rittberger, and Wagner, "Norms and Foreign Policy: Constructivist Foreign Policy Theory," 6.

27 Legro, "Which Norms Matter? Revisiting the 'Failure' of Internationalism," 35.

28 Ibid.

29 Boekle, Rittberger, and Wagner, "Norms and Foreign Policy: Constructivist Foreign Policy Theory," 6.

30 Marcus Colchester, "Colonizing the Rainforests: The Agents and Causes of Deforestation," in The Struggle for Land and the Fate of the Forests, ed. Marcus Colchester and Larry Lohmann (London: Zed Books, 1995), 2.

31 Arthur Max, 'Malaysia deforestation is three times faster than the rest of Asia combined', February 1, 2011,http:// www.huffingtonpost.com/2011/02/05/malaysia-deforestation-is_n_816779.html.

32 Dan Drollete, 'Plague of deforestation sweeps across Southeast Asia. Illegal logging and unchecked economic development are taking a devastating toll on forests', theguardian.com, 21 May 2013,http:/www.theguardian.com/environment/2013/may/20/deforestation-southeast-asia.

33 Krittivas Mukherjee,'Asia must reverse massive deforestation: U.N.', March 27, 2008, http://www.enn.com/ecosystems/article/33657.

34 Jukka Miettinen, Chenghua Shi and Soo Chin Liew. Deforestation rates in insular Southeast Asia between 2000 and 2010. Global Change Biology (2011) 17, 2261-2270, http://iva.aippnet.org/large-scale-opposition-among-borneo-villagers-to-deforestation/ 
Malaysian province of Sarawak is destroying $2 \%$ of its tropical forest annually, primarily to allow for the establishing of palm tree plantations. ${ }^{35}$ While such figures need to be treated cautiously, often reflecting the concerns of the actors promulgating them, it is clear that the problem of deforestation is both severe and ongoing [61-70].

The second major problem for the researcher is determining which actors contribute to the continuing deforestation. On the one hand, many global development agencies and intergovernmental bodies assert that poverty is the leading cause while ENGOs argue that TransNational Corporations (TNCs) feeding the excessive consumption of developed states is the true reason for tropical timber deforestation. ${ }^{36}$ The ITTO and the UN FAO list contributing factors causing deforestation as: agriculture and development policies, excessive fuelwood collecting, overgrazing, forest fires and overexploitation of timber and combined with poor harvesting techniques. ${ }^{37}$ Ongoing logging is cited merely as a factor that, "aggravates changes in forest cover." 38

ENGOs with an interest in forestry practices and other observers posit that logging is the primary cause of ongoing deforestation. ${ }^{39}$ The World Resource Institute in 1997 reported in The Last Frontier Forests: Ecosystems and Economies on the Edge that continued logging was a moderate to high threat to $50 \%$ of the remaining forestland in Asia, 69\% in South America and 79\% in Africa. ${ }^{40}$ In 1995 Nigel Dudley, Jean-Paul Jeanrenaud and Francis Sullivan in their report Bad Harvest: The International Tropical Timber Trade and the Degradation of the World's Forests argued that the ongoing timber trade was the principal reason for forest degradation and destruction. ${ }^{41}$ While both sides of the debate have a point, for the purposes of this paper it is not necessary to assess relative levels of blame but rather it can be asserted with confidence that all these differing activities contribute to the persistent problem of tropical forest deforestation.
Problematically, tropical forests are only considered valuable by their states as a source of timber or carbon, leading to a disinclination to promote ongoing conservationist forestry practices. ${ }^{42}$ For most Lesser Developed Countries (LDCs), the exploitation of state owned forests is essential to feed domestic industries and to develop an export sector to improve the economic lives of its citizens. ${ }^{43}$ The global tropical timber trade is an important, ongoing critical source of foreign exchange earnings for a number of states with large swathes of tropical forests. ${ }^{44}$ Such domestic pressure is augmented by global forces spearheaded by organisations such as the World Bank that insist, as a condition of loans lent to LDCs, that the states implement development projects and export-oriented economic policies, often to the detriment of the forest environment. ${ }^{45}$ Consequently, these states are forced to exploit their forests at an ever-greater rate to meet financial commitments. ${ }^{46}$

These combined two levels of pressure reinforce ongoing tropical forest exploitation in a continuing negative feedback loop required to satisfy internal and external constituencies. Without an understanding of these ongoing contextual pressures applied to LDC timber producer states, it is not possible to appreciate the actions of producer states within the ITTO to frustrate conservationist measures [71-80].

\section{Protecting tropical forests}

The ongoing destruction of tropical rainforests, raise intriguing questions of agency and conflicting interests and values as well as clashing environmental norms promulgated by various normative entrepreneurs. ${ }^{47}$ The destruction of the tropical forests has graduated to the level of a global issue where many individuals and states are concerned about the loss of such forests ecosystems and its concomitant impacts on biodiversity and climate change. ${ }^{48}$

35 Arthur Max, 'Malaysia deforestation is three times faster than the rest of Asia combined', February 1, 2011,http:// www.huffingtonpost.com/2011/02/05/malaysia-deforestation-is_n_816779.html

36 Colchester, "Colonizing the Rainforests: The Agents and Causes of Deforestation."

37 The London Environmental Economics Centre, "The Economic Linkages between the International Trade in Tropical Timber and the Sustainable Management of Tropical Forests," (London: International Tropical Timber Organisation, 1993).,Barbier et al., "Deforestation: The Role of the International Trade in Tropical Timber," 271., Chris Elliott and Richard Z. Donovan, "Introduction," in Certification of Forest Products: Issues and Perspectives, ed. Virgilio M. Viana, et al. (Washington, D.C.: Island Press, 1996), 3.

38 Smouts, Tropical Forests, International Jungle: The Underside of Global Ecopolitics, 88, 105., Gareth Porter and Janet Welsh Brown, Global Environmental Politics (Boulder: Westview Press, 1991), 97.

39 Ibid., p. 146., Smouts, Tropical Forests, International Jungle: The Underside of Global Ecopolitics, 105.

40 Dauvergne, Loggers and Degradation in the Asia-Pacific: Corporations and Environmental Management, 15.

41 Kibel, The Earth on Trial: Environmental Law on the International Stage, 127-28.

42 Ibid., 23

43 James J. Douglas, A Re-Appraisal of Forestry Development in Developing Countries (Boston: Martinus Nijhoff Publishers, 1983), 134.Ngau, Apoi, and Ling, "Malaysian Timber: Exploitation for Whom?," 42.

$44 \quad$ Barbier et al., "Deforestation: The Role of the International Trade in Tropical Timber," 277.

45 Peter Utting, Trees, People and Power: Social Dimensions of Deforestation and Forest Protection in Central America (London: Earthscan Publications Ltds, 1993), 37-8.

46 James Kahn and McDonald Judith, "International Debt and Deforestation," in The Causes of Tropical Deforestation: The Economic and Statistical Analysis of Factors Giving Rise to the Loss of the Tropical Forests ed. Katrina Brown and David W. Pearce (London: UCL Press Limited, 1994), 66., Oran R. Young and George J. Demko, "Improving the Effectiveness of International Environmental Governance Systems," in Global Environmental Change and International Governance, ed. Oran R. Young, George J. Demko, and Kilaparti Ramakrishna (Hanover: University Press of New England, 1996), 235-36.

47 Brunnee, "A Conceptual Framework for an International Forests Convention: Customary Law and Emerging Principles in Global Forests and International Law," 41

48 Smouts, Tropical Forests, International Jungle: The Underside of Global Ecopolitics, 9. 
Problematically for the global community, LDCS have argued citing international law precedents that states have the sovereign right to exploit their own resources, in particular as a form of restitution from imposed colonial practices. ${ }^{49}$ As explained above, these states have chosen to preference a norm of development. Thus, we can observe a contest between developmental and environmental norms within the global tropical timber regime [81-90].

Many scholars and popular writers have championed the need for rainforest conservation over development at all costs. ${ }^{50}$ The concept of Ecological Sustainable Development (ESD), based on conservationist ideals, has been incorporated with the tropical timber regime as Sustainable Forest Management (SFM) ${ }^{51}$ However, similarly to problems defining and implementing ESD, SFM is an elastically utilized term that enables stakeholders to argue a particular version of the concept that suits their agenda. While it has enjoyed success as a rhetorical device promoted by various stakeholders, it to date, has had little practical application within the regime. ${ }^{52}$

Another approach, promulgated in particular by certain developed states such as Britain and Australia is a preservationist approach that 'locks' away large areas as forest reserves and prohibits logging. Such an approach is needed it is argued because forestry exploitation, and biodiversity loss is occurring at such an accelerated pace, that sustainable approaches cannot keep up and consequently it is necessary to preserve such areas. ${ }^{53}$ However, as shall be observed, such preservationist arguments have failed to gain any purchase within the tropical timber regime. This has occurred due to a confluence of negating factors including vested domestic interests opposed to antilogging practices; preservationist advocating ENGOs being denied access and influence within the ITTO; and the development norm being privileged over good environmentalist outcomes in timber producing states.

It is clear that preservationist approaches have become marginalized within the ITTO and the broader global community debate on tropical forest usage. Smout maintains that conservationism has become dominant in the global tropical timber discourse without demonstrating the veracity of this assertion. ${ }^{54}$ While the language of conservationism has been widely adopted as an alternative to environmental exploitation within the global tropical timber discourse (in particular within ITTO documentation), it is not demonstrable that conservationism has been able to supplant exploitation as the underlying norm of the global tropical timber regime. The reasons behind this failure of norm entrepreneurs to impose conservationist or preservationist mores and practices on the states involved in the tropical timber trade is the central focal point of this paper [91-100].

\section{The International Tropical Timber Agreement (ITTA)}

Given that the mechanics of tropical forest destruction was so well understood for decades, inevitably there was a push for a protective environmental treaty and body. Unusually the impetus to protect tropical forest had its first concrete expression in the workings of the United Nations Conference on Trade and Development (UNCTAD). This body was dedicated to the goal of restructuring historical patterns of global trade to enable LDCs to both participate and derive greater benefits for their populaces. UNCTAD sought to pursue this laudable goal through attempts to trade in tropical timber. This focus on development and the impetus generated by an outside agency, rather than the affected states coming together to combat deforestation on their own, goes some way in explaining the truculence demonstrated by both producer and consumer timber states. ${ }^{55}$

Consequently, the road to creating a tropical timber agreement (which eventually became the ITTA) was anything but smooth and the document created was deficient in a number of ways. Starting in 1976 there was a series of preparatory meetings that continued for six years but ratification of the agreement did not occur until $1985 .{ }^{56}$ In the absence of state leadership, the drivers of the negotiations were International Organizations (IOs) and ENGOs that were determined to create a tropical timber conservationist regime. ${ }^{57}$ The lobbying of ENGOS such as the World Wildlife Fund WWF, the UK Friends of the Earth (FoE-UK) and the IO International Union for the Conservation of Nature (IUCN), and the efforts of some timber consumer states led to a negotiated text being agreed to by all states. ${ }^{58}$ The major producer and consumer states also achieved their goal of maintaining financial control of the fledgling body. For example, the ITTO budget for 1989 saw over $50 \%$ of the monies supplied by Japan, Brazil, Indonesia, Malaysia, the U.S.A. and Korea, all of which were heavily invested in the continuation of the global tropical timber trade..$^{59}$

49 Tarlock, "Exclusive Sovereignty Versus Sustainable Development of a Shared Resource: The Dilemma of Latin American Rainforest Management," 43. See for example, Permanent Sovereignty over Natural Resources,UN Resolution 1803 (XVII).

50 Alan Grainger, "The State of the World's Tropical Rainforests," Ecologist 10, no. 6 (1980); Adrian Forsyth and Kenneth Miyata, Tropical Nature: Life and Death in the Rainforests of Central and South America (New York: Simon and Schuster, 1984).; Susan Head and Robert Heinzman, eds., Lessons of the Rainforest (San Francisco: Sierra Club Books for Children, 1990)., Robert Goodland, ed., The Race to Save the Tropics: Ecology and Economics for a Sustainable Future (Washington D.C.: Island Press, 1990).

51 Ibid., 15. SFM's defining feature has been a conservationist one. That is of ensuring an unimpeded, continuing supply of timber for the foreseeable future. The value of a forest was primarily based on its function as a store of timber-not its biosphere as a whole. Andrew Robert Cock, "Tropical Forests in the Global State System," International Affairs 84, no. 2 (2008): 322.

52 Ibid., 184

53 Ibid., 172., Switzer, Environmental Politics: Domestic and Global Dimensions, 279.

54 Smouts, Tropical Forests, International Jungle: The Underside of Global Ecopolitics, 173.

55 Poore, Changing Landscapes: The Development of the International Tropical Timber Organization and its Influence on Tropical Forest Management, 27.

56 Kasimbazi, "Sustainable Development in International Tropical Timber Agreements," 141., Gale, "Discourse and Southeast Asian Deforestation: A Case Study of the International Tropical Timber Organization," 241., Poore, Changing Landscapes: The Development of the International Tropical Timber Organization and its Influence on Tropical Forest Management, 38.

57 Poore, Changing Landscapes: The Development of the International Tropical Timber Organization and its Influence on Tropical Forest Management, 14.

58 Fred P. Gale, The Tropical Timber Trade Regime, International Political Economy Series(New York: St. Martin's Press, 1998$), 87$. 
Radoslav Dimitrov's argues that both producer and consumer states were forced to participate in the ITTA negotiations because the "normative logic of appropriateness" requires nations to be seen to be actively participating in regime negotiations. ${ }^{60}$ This is because no state can afford the global opprobrium they would face for not being perceived to be taking preventative action on deforestation. ${ }^{61}$ Certainly at the time the ENGOs were working diligently to publicize ongoing global deforestation. ${ }^{62}$ Their efforts were successful in that people were becoming increasingly aware at this time of the loss of this resource and its effects. ${ }^{63}$ Such pressures on both producer and consumer states led to them agreeing to a draft document to avoid reputational costs and potential shaming as poor global environmental actors. ${ }^{64}$

The producer states certainly were interested in sourcing any potential funding such an entity might generate. Both producer and consumer nations, given the global pressure to resolve ongoing tropical forest degradation perhaps also saw that such an organization was inevitable and wished to ensure they were part of the body to maintain a voice in proceedings that would invariably affect their interests. The limited ITTA proposed (see below) allowed them the greatest potential latitude to continue a "business as usual" approach while maintaining the pretext that they were committed to conserving tropical forests. Further, despite agreeing to the limited ITTA, at least from an environmental protection perspective, the member-states, as shall be seen in the rest of the paper, continued to flout many of its provisions by continuing large-scale timber felling. Given there are no enforcement provisions in the ITTA, states have continued their ongoing exploitative behaviour of tropical gains, seeking to maximize short-term gains that benefited both the producer state's elites and the timber consumers of the importing states [101-108].

The ITTA is primarily a flawed commodities agreement that is deficient in required regulatory mechanisms or effective market intervention powers. Its goal is: "to promote sustainable development of tropical forests by encouraging and assisting the tropical timber industry and trade and thus conserve the resource base upon which they depend." 65 Fred Gale maintains that the ITTA was meant to be a conventional commodities agreement and was designed to stabilize the market price of tropical timber. However, by the time a draft agreement was promulgated it was perceived that tropical timber could not be regarded in such a light, due to the problematic nature of extraction. ${ }^{66}$ Ans Kolk concurs with the conclusion advanced by Gale that it was a commodities agreement but blames its inherent flaws on the attempted melding of conservation with trade promotion. ${ }^{67}$

The ITTA attempts (and fails) to balance these inherent contradictions when it: "attempted indirectly to conserve tropical forest resources by addressing uncertainty and fluctuation in the international market for tropical timber, with the idea that a more stable international market will allow states to choose when to harvest and sell their forest resources, rather than being driven to do so by market pressures or opportunities." ${ }^{\prime 8}$ Problematically this approach ended up putting in place a monopolistic cartel which likely led to incentives to exploit rather than conserve tropical timber. The states' short-term developmental interests are met by focusing on maintaining a steady import/export trade exclusively for the benefit of the cartel members.

The ITTA defined tropical timber in Article 2(1) as comprising, "non-coniferous tropical wood for industrial uses, which grows between the Tropic of Cancer and the Tropic of Capricorn...". 69

- To create an effective framework ensuring cooperation and consultation between tropical timber consumer and producer states.

- To ensure the diversification and expansion of the global tropical timber trade and improve market conditions.

- To promote and augment forestry research and development with the aim of improving tropical forest management and the use of wood products.

- To encourage national forestry policies that encouraged sustainability and conservationist practices of tropical forests and their resources. ${ }^{70}$

The two key objectives are couched in cooperative terms to promote the global tropical timber trade and sustainable practices to conserve tropical forests. While these are laudable joint goals the reality is that the two are often diametrically opposed. The mooted vital sustainability approach is undermined by the implicit rationale that as far as the negotiating states were concerned, "tropical forests would only continue to exist if they were used for an economic purpose - the most important being the production of wood."71

59 Ibid., 85 .

60 Radoslav S. Dimitrov, "Hostage to Norms: States, Institutions and Global Forest Politics," Global Environmental Politics 5, no. 4 (2005): 3.

$61 \quad$ Ibid.: 17

62 Switzer, Environmental Politics: Domestic and Global Dimensions, 277.

63 de Jong, Tuck-Po, and Ken-ichi, "The Political Ecology of Tropical Forests in Southeast Asia: Historical Roots of Modern Problems," 2.

64 Dimitrov, "Hostage to Norms: States, Institutions and Global Forest Politics," 4.

65 Chasek, Earth Negotiations: Analyzing Thirty Years of Environmental Diplomacy, 102.

66 Fred P. Gale, "The Mysterious Case of the Disappearing Environmentalists: The International Tropical Timber Organization," Capitalism, Nature, Socialism 7, no. 3 (1996): 106-07.

67 Ans Kolk, Forests in International Environmental Politics: International Organisations, Ngos and the Brazilian Amazon (Utrecht, Netherlands: International Books, 1996), 137.

68 Elizabeth R. DeSombre, The Global Environment and World Politics, International Relations for the 21st Century. (London: Continuum, 2002), 149

69 Beatrice Chaytor, "The Development of Global Forest Policy: Overview of Legal and Institutional Frameworks," (International Institute for Environment and Development

World Business Council for Sustainable Development, 2001), 16.

70 Chasek, Earth Negotiations: Analyzing Thirty Years of Environmental Diplomacy, 95. 
The fact conservationist language was included at all in the objectives was due to the effective lobbying by ENGOs, and IOs including the WWF, IUCN, FoE-UK and the International Institute for the Environment and Development (IIED) which were observers at the negotiations closing sessions. ${ }^{72}$ In this case it is observable that the various ENGOs and IOs acted as the key normative entrepreneurs to incorporate the norm of conservation within the ITTA and the concomitant body the ITTO. An analysis of the available primary documents of the negotiations and the secondary material indicates no efforts by these groups to argue for preservationist norms to underpin the Agreement. It is arguable that the environmental groups, well aware of the hostility from the coalition of producer and consumer states as well as timber companies, understood their only hope was to start with the less ambitious goal of embedding conservation goals within the text and incorporating preservationist environmental objectives at a later date. Further, the absence of more preservationistleaning ENGOs such as Greenpeace enabled groups that traditionally espoused a conservationist ethos, e.g. the IUCN and the WWF to have a greater influence on the environmental direction of the negotiations.

Consequently, Article $1(\mathrm{~h})$ was inserted into the text with the following environmental aim:

To encourage the development of national policies aimed at sustainable utilization and conservation of tropical forests and their genetic resources, and at maintaining the ecological balance in the regions concerned. ${ }^{73}$

On the face of it there appears to be a positive environmental outcome however, a closer examination of the ITTO demonstrates that neither producer nor consumer states have made conservation a priority over ongoing exploitation. ${ }^{74}$ As David Humphreys notes:

Neither the producers nor the consumers have contested the economic exploitation [my italics] of tropical forests for timber and for other forest products. Given this, and given also the conservation mandate of the ITTO, it is perhaps not surprising that the ITTO guidelines for the sustainable management of natural forests reflect inconsistencies between developmental and ecological objectives. ${ }^{75}$
The Preamble of the ITTA also captures this duality when it recognizes the: "importance of, and the need for, proper and effective conservation and development of tropical timber forests with a view to ensuring their optimum utilization while maintaining the ecological balance of the regions concerned and of the biosphere." ${ }^{\prime 6}$ The tension between the two dichotomous goals of timber exploitation and SFM has led to many of the internal problems within the ITTO as it tries to balance the competing interests.

Over the lifetime of the body it has become clear that the conservationist section of the ITTA is essentially at odds with the "expansion and diversification" goal of the ITTA. ${ }^{77}$ The 1990 Possible Action 33Report exposed even more baldly the dichotomy between the ITTO's position on conservation versus development/trade when it declared that any environmental impact studies undertaken should, "assess compatibility of logging practices with declared secondary [my italics] objectives such as conservation and protection."78

The ITTA's environmental goals are ineffective since it fails to allow for the critical issue of forest diversity which is key to a sustainable forest ecosystem. Kasimbazi correctly argues that the ITTA's emphasis on conservationist values, to the exclusion of preservation mores undermines the entire Agreement, since it does not support the tropical forest biosphere. ${ }^{79}$

\section{The International Tropical Timber Organization}

The states that negotiated the ITTA created a body (the ITTO) to administer the tropical timber regime. ${ }^{80}$ The organisation has provided a forum for debates between various norm entrepreneurs as to which environmental norm should underpin the organization, and by extension the tropical timber regime. ${ }^{81}$ Since its inception the body has become the premiere body governing the tropical timber trade and implementing SFM and now competes with the traditional forest organization the FAO, in the provision of tropical forest related information. ${ }^{82}$

71 Poore, Changing Landscapes: The Development of the International Tropical Timber Organization and Its Influence on Tropical Forest Management, 40.

72 Gale, "Discourse and Southeast Asian Deforestation: A Case Study of the International Tropical Timber Organization," 241.At the first ITTO Meeting, ENGOs were granted observer status only to the entities Meetings as were timber companies. D. Humphreys, "Ngo Influence on International Policy on Forest Conservation and the Trade in Forest Products," in Ngo Diplomacy: The Influence of Nongovernmental Organisations in International Environmental Negotiations, ed. Michele M. Betsill and Elisabeth Corell (Cambridge, M.A.: MIT Press, 2008), 163.

73 David Humphreys, "Redefining the Issues: Ngo Influence on International Forest Negotiations," Global Environmental Politics 4, no. 2 (2004): 54.

74 Poore, Changing Landscapes: The Development of the International Tropical Timber Organization and Its Influence on Tropical Forest Management, 43 .

75 D. Humphreys, "Hegemonic Ideology and the International Tropical Timber Organization," in The Environment and International Relations, ed. John Vogler and Mark F. Imber (London: Routledge, 1996), 226.

76 "International Tropical Timber Agreement 1983," (1983).

77 Friends of the Earth and World Rainforest Movement, "The International Tropical Timber Agreement: Conserving the Forests or Chainsaw Charter? A Critical Review of the First Five Years' Operations of the International Tropical Timber Organization," (Friends of the Earth, 1992), 4.

78 International Tropical Timber Organization, "Technical Series 5: Itto Technical Guidelines for the Sustainable Management of Tropical Resources," (Yokohama: 1990), 9.

79 Kasimbazi, "Sustainable Development in International Tropical Timber Agreements," 146.

80 Porter and Brown, Global Environmental Politics, 100.

81 Gale, "Discourse and Southeast Asian Deforestation: A Case Study of the International Tropical Timber Organization," 243.

82 Smouts, Tropical Forests, International Jungle: The Underside of Global Ecopolitics, 144 
The structure of the ITTO is a peculiar one that privileges environmental exploitation. It is more akin to certain corporate structures. There are two types of official members comprising both producing and consuming states (one thousand votes each). ${ }^{83}$ The first 400 votes are set aside equally for producer states from Africa, AsiaPacific and Latin America. A proportion of 300 votes are divided between nation-states determined by their relative share of domestic tropical forests. The final tranche of 300 votes are apportioned by the average of the values of each producer states' net exports of tropical timber carried out over the previous three years (Article 10 (2) ITTA 1983).

While this system allows all states with tropical forests a say in proceedings, it allows states with large forest regions and export industries such as Malaysia, Indonesia and Brazil, a disproportionate say in the workings and direction of the ITTO. It also encourages ongoing, greater despoliation of the forests because the greater the volume of tropical timber exported, the more votes are assigned to a state thus rewarding exploitive behaviour with greater sway in the ITTO ${ }^{84}$ From the beginning the ITTO voting mechanism ensured that conservationist aims would be considered secondary to the putative need to expand the global timber trade. ${ }^{85}$

The timber consuming nations are accorded an initial ten votes each. The remaining votes are ascertained by the average volume of their net imports of tropical timber during the previous three year period, determined from a starting point four years prior to the allocation of votes (Article 10(5) ITTA 1983). Regretfully, such a system penalizes nations that focus importing higher-value goods e.g. furniture, in favour of states (e.g. Japan) that concentrate on importing huge quantities of unprocessed logs for their industries. ${ }^{86}$ While the ITTO voting procedures can appear to promote discord in practice the majority of decisions are produced via consensus between the producer and the consumer coalitions given their interests often converge. $^{87}$

The ITTA conferred voting rights on states only and merely asks that its members should "cooperate" with ENGOs to avoid ongoing duplication of efforts (Article 14(2) ITTA 1983).ENGOs can participate in Council Meetings as Observers (Article 15 ITTA 1983), but the ITTA was not configured to allow for increased ENGO presence over time. Such an integral failure to allow ENGOs to effectively contribute to the organisation has been to the ITTO's detriment in achieving its stated environmental goals. ${ }^{88}$ Another structural deficiency is that the ITTA does not confer on the International Tropical Timber Council (ITTC), the deliberative body of the ITTO, any specific powers or mandates (e.g. submitting proposals to further conservationist ends). ${ }^{89}$ The ITTC has no monitoring or enforcement powers, it cannot even force member states to provide an Annual Report. ${ }^{90}$

On the face of it, producer states have more influence on the ITTC given the weighted voting system. Given that power it can be observed that timber producer states have been dominant in negotiations. This has led over time to a dilution of the environmental objectives of the ITTA as they have been perceived as interfering with production schedules. ${ }^{91}$ Producer states like Brazil, Malaysia and Indonesia have due to their outsized influence, formed an effective veto coalition with the aim of blocking measures that aim to limit the timber production coalition..$^{92}$ Porter and Brown however, have pointed out that the true power in the ITTO is wielded by consumer states such as Japan, the European Union and the U.S. whose interests are to ensure that the currently unsustainable tropical timber exports to their economies are maintained. ${ }^{93}$

Nicholas Guppy is particularly critical of the role Japan has played over the years in stymieing effective tropical forest environmental protections. The ITTO was originally envisaged a "world forum" to balance promoting the tropical timber trade goal with the conservation of tropical forests. Guppy argues that Japan, whose consumers appetites for tropical timber is voracious, has acted to keep timber prices low. Japan has also had an outsized influence in the ITTO since it provides a major part of the entities' funding and hosts the ITTO's headquarters. Japan has consequently been in a strong position to influence the ITTO but to date has not been an effective advocate for forest sustainability since it perceives that such an outcome would negatively impact its economic needs. ${ }^{94}$

Thus we can observe two powerful veto coalitions converging to prevent any environmental challenges to their vested economic interests. This coming together of both exporting and importing timber states, dedicated to ongoing timber exploitation, makes the incorporation of conservationist norms within the ITTO difficult to implement by norm entrepreneurs.

Early on, producer and consumer states set up separate caucuses within the framework of the ITTO meetings. These coalitions specifically excluded ENGOs from participating. This diminished the ENGOs ability to present environmental arguments and estopped

83 Chaytor, "The Development of Global Forest Policy: Overview of Legal and Institutional Frameworks," 17.

84 Gale, "The Mysterious Case of the Disappearing Environmentalists: The International Tropical Timber Organization," 107-08.

85 Colchester, "The International Tropical Timber Organization: Kill or Cure for the Rainforests?," 189.

86 Gale, "The Mysterious Case of the Disappearing Environmentalists: The International Tropical Timber Organization," 108.

87 Gale, "Discourse and Southeast Asian Deforestation: A Case Study of the International Tropical Timber Organization," 240.

88 David VanderZwaag and Douglas MacKinlay, "Towards a Global Forest Convention: Getting out of the Woods and Barking up the Right Tree," in Global Forests and International Environmental Law, ed. Canadian Council of International Law. (London: Kluwer Law International 1996), 12-14.

89 Chaytor, "The Development of Global Forest Policy: Overview of Legal and Institutional Frameworks," 17.

90 International Tropical Timber Organization, "About ITTO," http://www.itto.or.jp/live/PageDisplayHandler?pageId=225.

91 Kolk, Forests in International Environmental Politics: International Organisations, Ngos and the Brazilian Amazon, 137.

92 Ibid., Smouts, Tropical Forests, International Jungle: The Underside of Global Ecopolitics, 146.

93 Porter and Brown, Global Environmental Politics, 100-01., Smouts, Tropical Forests, International Jungle: The Underside of Global Ecopolitics, 146.

94 Nicholas Guppy, "International Governance and Regimes Dealing with Land Resources from the Perspective of the North," in Global Environmental Change and International Governance, ed. Oran R. Young, George J. Demko, and Kilaparti Ramakrishna (Hanover, N.H.: University Press of New England, 1996), 141. 
them from framing the debate in environmental rather than purely economic terms.${ }^{95}$ Such exclusionary tactics costing ENGOs a "seat at the table" has led to an institutional failure in achieving sustainable forestry outcomes. Even more problematically, any research projects undertaken by the ITTO to date has tended to focus primarily on tropical timber to the detriment of tropical forests programmes. The conservation of forests has been, at best, an incidental goal. Kasimbazi argues that such an emphasis has invariably led to a diminution of ecological values and a deterioration in contiguous forests. ${ }^{96}$

\section{The ITTO and the Year 2000 Objective}

The ITTO Report entitled No Timber without Trees in 1989 concluded that the vast majority of the world's tropical forests were not being managed sustainably (despite the ITTO), and that they would be logged to the point of extermination unless urgent action was undertaken..$^{97}$ The ITTC's response was to wait until June 1991 and establish the "Year 2000 Objective". This set a goal asking the ITTO to "endeavour" to ensure that the global tropical timber trade was sustainably managed by the end of the millennium century. ${ }^{98}$ Poore considers this goal was the most critical policy step as yet undertaken by the ITTO. ${ }^{99}$ To assist states in achieving this laudable goal the ITTO set up a fund for sustainable management of forests (the Bali Partnership Fund). The Fund aimed to help members make wise investments with the overall aim to increase a state's capacity to implement domestic sustainable timber programmes. ${ }^{100}$

While both producer and consumer countries were willing to accede to a general target, the majority of member-states were against the adoption of specific targets. For example, the U.S.A. maintained that for them it was necessary that any, "...target does not carry implications for our government's trade policy."101 Clearly, for these states meeting such a declared ambitious target was not going to be met without radical action that they were unwilling to entertain. A subsequent examination of events demonstrates fears over the sincerity and commitment of the ITTO member's commitment to sustainability were well grounded. The Review of Progress towards the Year 2000 Objective determined that while there were signs of improvement on this issue a great deal more action was urgently needed. ${ }^{102}$ It was also evident that the funding commitments agreed to be the member-states to be paid towards the Bali Fund were neither clear nor powerful given that they relied merely on voluntary contributions to effect change. ${ }^{103}$

The lack of discernible action towards integrating ecological sustainability practices within the ITTO led to increasing disenchantment on the part of ENGOs and this manifested at the ITTC meetings of the period. At the 10th Session of the Council in Quito, Ecuador, in May 1991, Chris Elliott of the WWF spoke for many ENGOs when he protested that the proceedings were degenerating into mere, “...fruitless discussions, bargaining on projects concluded without transparency and the perceived lack of many delegate's commitment to the ITTA, 1983, the Action Plan and Target 2000."104 By the May 1992 Council Meeting in Yaounde, disillusionment with the ITTO by ENGOS was near absolute. Theo Anderson of the Ghanian branch of FoE-UK, declared that, "[t]oo much time was devoted to projects and not enough to policy."105

\section{The Year 2000 Report}

The ITTO members made a rod for their backs when they made such extravagant claims for themselves when setting the Year 2000 objective. The requirement that member states' tropical forests to be sustainably managed by then would have been difficult even with the wholehearted support of the participants. The organisation needed to show real progress had been achieved or acknowledge that the ENGO's criticisms of its slow progress to implement sustainability goals were accurate.

To obviate such criticisms in late 1999 the ITTO commissioned another Study, (Decision 10 (XXVI)) to determine two things: member's progress towards incorporating sustainability into their domestic programmes, and the ITTOs' own performance as an organization in meeting its professed aims. ${ }^{106}$ Duncan Poore and Thang Hooi Chiew undertook the Review of Progress towards the Year 2000 Objective in November 2000. Regrettably, as Poore himself conceded, the Report was deeply flawed from its inception. All of the

\footnotetext{
95 Poore, Changing Landscapes: The Development of the International Tropical Timber Organization and its Influence on Tropical Forest Management, 45.

96 Kasimbazi, "Sustainable Development in International Tropical Timber Agreements," 144-45.

97 Duncan Poore et al., No Timber without Trees: Sustainability in the Tropical Forest (London: Earthscan Publication Ltd, 1989$), 196$.

98 "ITTO Yokohama Action Plan 2002-2006," in ITTO Policy Development Series No. 11 (International Tropical Timber Organization, 2002), iii.

99 Poore, Changing Landscapes: The Development of the International Tropical Timber Organization and its Influence on Tropical Forest Management, 72.
}

100 Chasek, Earth Negotiations: Analyzing Thirty Years of Environmental Diplomacy, 101.

101 Poore, Changing Landscapes: The Development of the International Tropical Timber Organization and its Influence on Tropical Forest Management, 73.

102 "ITTO Yokohama Action Plan 2002-2006," iii.

103 Chaytor, "The Development of Global Forest Policy: Overview of Legal and Institutional Frameworks," 20.

104 Poore, Changing Landscapes: The Development of the International Tropical Timber Organization and its Influence on Tropical Forest Management, 106.

105 Ibid., 108.

106 Poore, Changing Landscapes: The Development of the International Tropical Timber Organization and its Influence on Tropical Forest Management, 172. 
member states refused to answer the key question about the Year 2000 Objective: "...how much of the timber exported came from sustainably managed resources, and what area of forest was under demonstrably sustainable management?"107

Given the lack of engagement by member-states the authors were forced to concede that the Year 2000 Objective should be considered more a progression rather than a goal and that, "...the process, in the view of the consultants, should be to move as swiftly as possible in the direction of that goal." 108 The authors also acknowledged that the initial symbiotic relationship between the ITTO and the ENGOs had irretrievably broken down, “...because [the] ITTO did not and, by the nature of the fundamental changes it was trying to bring about, could not move as fast as the NGOs wished it to."109 The Report's final recommendations to one, to continue helping producer states to meet the SFM criteria and two, to make the ITTO more efficient did not lead to any formal decisions due to, as Poore wrote, "a failure of procedures rather than will." 110 The ITTO's member-states inability however, to put in place the Report's recommendations suggests the problem was not so much a procedural error as intimated, but rather a lack of desire on the part of the delegate states to implanting conservationist mores.

Further, producer states, considered targets like the Year 2000 Objective to be merely advisory rather than binding. ${ }^{111}$ holder, it has generally been able to enforce its will at the expense of SFM. ${ }^{112}$

Rather than grapple with its institutional issues the ITTC turned to what it knew best, the creation of more Action Plans to ostensibly address the sustainability issue. The Yokohama Action Plan was adopted in November 2000, which built on and replaced the previous Libre Action Plan. While it sharpened focus compared to the previous Libre Plan, (it reduced to six, as opposed to nine, the stated goals) and adds a new action that aimed, "...to encourage and assist individual producing member countries to identify and address constraints in their implementation of sustainable forest management and the sustainable development of the forest industry." 113
The ITTO was aware of its deficiencies when it came to the implementation of sustainability norms. The ITTC's Decision 2 (XXIX) saw the members agree to move as quickly as feasibly possible to allow tropical timber exports only sourced only from sustainably managed forests. ${ }^{114}$ To achieve this goal the ITTC proposed to:

Support the effective enforcement of forest laws and regulations that ensure sustainable forest management and secure the production base.

Support networking and the exchange of information with relevant international organizations to maintain the integrity of the resource base, including protected area networks.

Promote the conservation, rehabilitation and sustainable management of threatened forest ecosystems...in collaboration with relevant organizations. ${ }^{115}$

Again problematically, the reports submitted by member-states verifying compliance with the agreed to Year 2000 Objective requirement were mostly inaccurate. For example, the Mission to Indonesia Report (2000) findings were virtually the opposite of the official Indonesian Report it provided to meet its Year 2000 Objective requirements. ${ }^{116}$ Such a deficiency prevented the ITTO from properly assessing the scope of the problem, let alone engaging with it. The ITTO has adopted a new Action Plan 20013-2018 to succeed the Yokohama Plan. The Plan is hailed by the ITTO as a "bold plan" with "ambitious targets"(p.4). ${ }^{117}$ It puts in place six strategic goals that member-states are expected to implement over the five-year plan. They are:

Promote Good Governance and Enabling Policy Frameworks for Strengthening SFM and Related Trade, and Enhancing SFM Financing and Investment Strategic Priority.

Increase the Contribution of Tropical Forests to National and Local Economies, Including through International Trade.

Enhance the Conservation and Sustainable Use of Biodiversity in Tropical Timber Producing Forests.

\footnotetext{
107 Ibid

108 Duncan Poore and Thang Hooi Chiew, "Review of Progress Towards the Year 2000 Objective," (International Tropical Timber Council, 2000), 4.

109 Ibid., 14-15.

110 Poore, Changing Landscapes: The Development of the International Tropical Timber Organization and its Influence on Tropical Forest Management, 210, 13.

111 Smouts, Tropical Forests, International Jungle: The Underside of Global Ecopolitics, 148.

112 Elliott, The Global Politics of the Environment, 85

113 "ITTO Yokohama Action Plan 2002-2006," iii.

114 Ibid., 4.

115 Ibid., 11

116 Poore, Changing Landscapes: The Development of the International Tropical Timber Organization and its Influence on Tropical Forest Management, 218.

117 ITTO Strategic Action Plan 2013-2018, http://www.itto.int/files/user/pdf/publications/ENGLISH_ACTION_PLAN_2013_2018.pdf, p.4.
} 
Reduce Tropical Deforestation and Forest Degradation and Enhance the Provision of Environmental Services.

Improve the Quality and Availability of Information on Tropical Forests, Forest Product Markets and Trade.

Build and Develop Human Resource Capacity to Implement SFM and Increase Trade in Forest Goods and Services from Sustainably Managed Forests. ${ }^{118}$

Problematically, though and as the Report's writers freely admit, the ITTO is reliant upon voluntary contributions from its member-states to achieve these goals. Its own price tag for successfully implementing these goals in the specified time period is US\$200 million. ${ }^{119}$ Since its inception the ITTO has only been given US $\$ 300$ million is by its members so this is a highly ambitious funding target that is unlikely to be met. ${ }^{120}$ Further, while they are laudable goals, they are remarkably similar to previously expressed goals in various ITTO plans. Given the previous failures in implementing previous plans it is not likely that the current iteration of the Action Plan will have any more success in achieving positive environmental outcomes than its predecessors.

\section{The 1994 Successor Agreement Negotiations}

The negotiations to create a successor ITTA provided an opportunity to alter the direction of the ITTO and put in place a stronger commitment to conservationist norms. The renegotiations began in 1993, taking a year to finalize and was adopted on the 26th January 1994. ${ }^{121}$ It was opened for signature on 1st April 1994, entered into force on 1st January 1997 and is almost identical to the previous Convention. ${ }^{122}$ Poore described the new agreement as a victory for common sense but it could more easily be perceived as merely a continuation of the status quo. It certainly was a missed opportunity to fix the problems that had become so apparent to ENGOs and other concerned actors. ${ }^{123}$
The Successor Agreement, at least rhetorically, promoted a stronger emphasis on sustainability, but remained limited to tropical forests. For our purposes the key Aims of the 1994 ITTA were:

(c) To contribute to the process of sustainable development;

(d) To enhance the capacity of members to implement a strategy for achieving exports of tropical timber and timber products from sustainably managed sources by the year 2000 ;

(e) To promote the expansion and diversification of international trade in tropical timber from sustainable sources [my emphasis] by improving the structural conditions in international markets, by taking into account, on the one hand, a long term increase in consumption and continuity of supplies, and, on the other, prices which reflect the costs of sustainable forest management and which are remunerative and equitable for members, and the improvement of market access. ${ }^{124}$

While the language again reflects the need for ESD, conserving forests, and non-economic valuing of forests, there was no mechanism in the Successor Agreement to bring about such lofty objectives. It was further limited in that it only applied to tropical timber; new funding commitments were nebulous; there was no mechanism for ENGOs or the indigenous peoples affected by member-state activities to actively engage with the organisation and it remained primarily a commodities agreement. ${ }^{125}$ Article 15 of the Successor Agreement allowed the Council to invite ENGOs (or other organizations referred to in Article 14, 20 or 29 of the current Agreement) with an interest in tropical forests to attend Council Meetings as observers only thus stopping well short of making these groups true partners in achieving tropical forest sustainability. ${ }^{126}$

The 1994 ITTA was for an initial five-year period but was extended twice for three-year terms. ${ }^{127}$ The controversial voting structure that had helped impede environmental progress was retained in Article

\footnotetext{
118 Ibid.

119 Ibid., pp. 14, 17

120 Ibid., p. 7.
}

121 The negotiations were held in at the Palais des Nations, Geneva, Switzerland: the first from 13 to 16 April, 1993 , the second from 21 to 25 June 1993, the third from 4 to 15 October 1993 and the fourth was held from 10 to 26 January 1994. The negotiations were attended by representatives of 57 states (55 as participants and 2 observers). International Tropical Timber Organization, "International Tropical Timber Agreement," United Nations Conference on Trade and Development, http://www.itto.or.jp/live/PageDisplayHandler?pageId=201.

122 Chasek, Earth Negotiations: Analyzing Thirty Years of Environmental Diplomacy, 101., Lorraine M. Elliott, The Global Politics of the Environment (Hampshire: Macmillan, 1998), 85.

123 Poore, Changing Landscapes: The Development of the International Tropical Timber Organization and its Influence on Tropical Forest Management, 125.

124 International Tropical Timber Organization, "International Tropical Timber Agreement."

125 Kasimbazi, "Sustainable Development in International Tropical Timber Agreements," 150-51.

126

Ibid.

127 Flejzor, "Reforming the International Tropical Timber Agreement," 21. 
10. ${ }^{128}$ Article 2 put in place the aforementioned "Bali Fund" aiming to help producer states members make the needed investments to sustainably manage their tropical timber reserves (objective $1(\mathrm{~d})$ ). ${ }^{129}$ Regrettably the fund has been a failure due to chronic under-funding by the consumer states despite stated pledges. ${ }^{130}$

\section{Successor Agreement to the International Tropical Timber Agreement 2006}

With the 1994 Successor Agreement concluding in 2004 UNCTAD again convened a Conference to create a further Agreement. The first session occurred from the 26-30 July 2004 in Geneva. ${ }^{131}$ While the major producer and consumer coalitions attended, due to ENGO disillusion (with the only the IUCN and FoE-UK (International) being present), which were specially invited, chose to attend the meetings. ${ }^{132}$ The negotiations reflected a growing 'corporatisation' within the ITTO with most of the delegates being timber trade advisors whose first loyalty was ensuring the ongoing viability of the global timber business. ${ }^{133}$

At the First Session there was discussions about the importance of SFM and the need for the ITTO to take a long-term approach to the issue. Regrettably the ITTO objectives on SFM always appear to be a long-term goal rather than an urgent priority. Objective (b) of the proposed Successor Agreement was tentatively put as (sections in brackets indicate points not agreed):

[To promote sustainable forest management] to enhance the [long term] capacity [and efforts] of members to implement a strategy for achieving exports of tropical timber and timber [and non-timber] products from sustainably managed forests [while conserving other forest values] [or sources]. ${ }^{134}$

The focus of the Successor Agreement again was on timber rather than holistically considering tropical forests (Preamble, section (e)). ${ }^{135}$ For the first time this section made it clear that timber should be considered a vital part of the producer states' economic interests.
According to Flejzor the negotiators considered the vexing issue of expanding the ITTA to include all types of forests but in the final draft there was no sign of this, surely another missed opportunity by the ITTO. ${ }^{136}$

At the Second Part of the Conference in Geneva (27 June-1 July 2005), a new section was added to both the Preamble (c) and Article 1 of the Objectives regarding producer states' exploitation of their tropical forests. ${ }^{137}$ The section was retained in the final draft as Section (d) of the Preamble and reads:

Recognizing that States have in accordance with the Charter of the United Nations and the principles of international law, the sovereign right to exploit their own resources pursuant to their own environmental policies and have the responsibility to ensure that activities within their jurisdiction and control do not cause damage to the environment of other States or of areas beyond the limits of national jurisdiction, as defined in principle 1(a) of the Non-Legally Binding Authoritative Statement of Principles for a Global Consensus on the Management, Conservation, and Sustainable Development of all Types of Forests. ${ }^{138}$

This newly included section enshrines the long-standing principle of customary international law reaffirming the sovereign right of states to exploit resources within their own national boundaries expressed (Principle 21 of the Stockholm Declaration and the Rio Declaration on Forests). ${ }^{139}$ It also arguably enshrines environmental exploitation as the governing norm of the tropical timber regime since the section effectively prevents global agents from interfering in the destruction of tropical forests. States can now cite this section to curtail outside interference with their exploitative activities leaving global actors limited options (e.g. moral suasion approaches which have proved extremely limited in this context) to prevent ongoing deforestation. It certainly appears to be a backward step whereby the ITTO has capitulated to the economic interests of producer states at the expense of sound environmental forestry practices. The latest iteration only requires member-states to develop domestic policies encouraging,

128 International Tropical Timber Organization, "International Tropical Timber Agreement."

129 Ibid.

130 Flejzor, "Reforming the International Tropical Timber Agreement," 21.

131 "Working Document Resulting from the First Session", (paper presented at the Conference for the Negotiation of a Successor Agreement to the International Tropical Timber Agreement, Geneva, Switzerland, 26-30 July 2004).

132 Participants listed in "Working Document Resulting from the First Session", (paper presented at the Conference for the Negotiation of a Successor Agreement to the International Tropical Timber Agreement, Geneva, Switzerland, 26-30 July 2004).

133 Humphreys, Logjam: Deforestation and the Crisis of Global Governance, 218.

134 "Working Document Resulting from the First Session", (paper presented at the Conference for the Negotiation of a Successor Agreement to the International Tropical Timber Agreement, Geneva, Switzerland, 26-30 July 2004)., 4.

135

136 Flejzor, "Reforming the International Tropical Timber Agreement," 20.

137 "Final Working Document Resulting from the Second Part of the Conference", (paper presented at the Conference for the Negotiation of a Successor Agreement to the International Tropical Timber Agreement, Geneva, Switzerland, 27 June - 1 July 2005$), 2$.

138 "International Tropical Timber Agreement 2006."http://www.ito.or.jp.

139 Chaytor, "The Development of Global Forest Policy: Overview of Legal and Institutional Frameworks," 5-6. 
"conservation of timber producing forests...maintaining ecological balance, in the context of the tropical timber trade."140

Again the flawed decision-making structure is left as is with the distribution of votes remaining the same as adopted in previous Agreements. ${ }^{141}$ Given the moribund voting structure and the vested interests it helps protect, it appears unlikely that ENGOs and conservationist-minded states like Britain will be able to effect change. Thus it appears highly probable that the ITTC will remain deadlocked, unable to enact needed environmental measures. The 2006 Successor Agreement superseding the 1994 Treaty was adopted in Geneva, Switzerland on the 27th of January 2006 by the member-states and entered into force in 2011 and is currently the operative agreement governing the global tropical forests and its timber trade. ${ }^{142}$

\section{The Robustness of Environmental Norms Underpinning the ITTO}

Applying Legro's test for norm robustness to the tropical timberregime, it is clear that those entrepreneurs promulgating positive environmentalist norms within the ITTO are struggling to make headway. Further, producer states, and some consumer states like Japan, have constantly fought to dilute even the weak environmental restrictions agreed to by member-states. The flawed institutional structure of the ITTO that rewards exploitationist behaviour has also impeded agreed to conservationist standards and their implementation. The norm of preservation has barely been discussed within the forum of the ITTO since the focus has been on continuing the tropical timber trade rather than 'locking' away vast swathes of forest from economic activity. Consequently, given that currently no such practices are applied to tropical timber, the norm in the context of tropical forests cannot be measured using the Legro test. Thus, the normative battle has been fought between those seeking to continue the status quo of ongoing exploitation, and actors like ENGOs seeking to implement conservationist mores as the standard of the ITTO.

The writing into the current Agreement of the section espousing an exploitative approach is just one pointer of the relative strength of the ITTO's members privileging the norm of exploitation, at the expense of conservation. Further, under the aegis of the ITTO the global logging industry has actually expanded in scope and size, and thus ongoing exploitationist practices have become further entrenched as the dominant norm. Sadly, it is now virtually beyond dispute that global stocks of tropical forests are being decimated to the point that if current trends continue, there is a real risk of extinction for broad swathes of forests and global biodiversity stocks despite the ITTOs mandate to protect such areas. ${ }^{143}$

As regards norm specificity, the conservation norm rates badly given that the current guidelines on SFM are poorly articulated and not well understood by member states. The notion of sustainability has long been considered a "motherhood statement" in that it has multiple and oft-times conflicting definitions of the term. Thus they are open to interpretation and has allowed member-states to proclaim their willingness to adhere to the guidelines without their being any criteria to enable their claims of sustainability to be tested.

In terms of normative durability, the norm of conservation has unfortunately been violated many times during the lifetime of the tropical timber regime not withstanding frequent paeans to the need for conservation. Violators of the conservationist norm, as been demonstrated above, face no penalties from either the ITTO or other member-states. Instead what can be observed is a "shifting of the goal posts" to ensure no member-state is a declared violator or states have refused to engage with the process of compliance verification without penalty.

Despite lip service paid to the term, conservation standards of behaviour have not been widely accepted by the ITTO member states and thus the member-states' degree of concordance must be assessed as having a low commonality. The major problem is that conservationist concepts have been incorporated into the "content" of ITTO and state forest polices without affecting actual ongoing detrimental practices on the ground. ${ }^{144}$ Given the low commonality of the conservationist norm, it would be absurd to attempt to assess the internalization of the conservationist norm by member-states since it clearly has not risen to that level of behavioural change.

The ITTO's own figures and reports such as the Year 2000Report reveal that the situation, while slightly improved as regards administrative, legislative and regulatory functions, still reveals massive over-logging occurring. ${ }^{145}$ Compounding the problem of knowing what is happening on the forest floor it is also clear that the official figures are being grossly underreported by states with a clear motive to disguise the real situation to allow exploitation to continue unimpeded. ${ }^{146}$ Consequently, utilizing the Legro test, the robustness of the conservationist norm should be assessed as low.

140 Preamble, (m),International Tropical Timber Organization, "International Tropical Timber Agreement, 2006," United Nations Conference on Trade and Development, http://www.ito.or.jp.

141 "International Tropical Timber Agreement 2006."

142 Deborah Davenport, S. et al., "Summary of the Forty-Fourth Session of the International Tropical Timber Council and Associated Sessions of the Four Committees: 3-8 November 2008," Earth Negotiations Bulletin 24, no. 81 (2008): 2.; International Tropical Timber Organization, "Decision 7(XLIV) Entry into Force of the International Tropical Timber Agreement, 2006," http://www.ito.or.jp.; "International Tropical Timber Agreement, 2006", http://www.itto.int/itta/

143 Colchester, "Colonizing the Rainforests: The Agents and Causes of Deforestation," 2.

144 Dauvergne, Loggers and Degradation in the Asia-Pacific: Corporations and Environmental Management, 157.

145 Smouts, Tropical Forests, International Jungle: The Underside of Global Ecopolitics, 188.

146 Ibid., 211. 


\section{Conclusion}

From its inception, the ITTO was concerned primarily with maintaining the status quo and has allowed exploitationist practices regarding tropical timber extraction to continue virtually unabated. Despite the organisations mandate to balance commercial and sustainability goals, good environmental outcomes have always been subsumed to ensuring a steady stream of tropical timber. Utilizing Legro's normative analysis it is clear that the environmental norms of conservation and preservation have not brought about substantive environmental action by ITTO members. Rather, the adoption by member-states of the semantics of environmentalism has only affected the symbolic behaviour of states, rather than affecting positively the implementation of SFM. ${ }^{147}$

The problem was that timber states, both producers and consumers never had 'buy in' in the ITTO. The impetus was provided by ENGOS and IOs in the futile hope that states would 'learn' and their behaviour would evolve. Rather producer states, looking to continue to enjoy revenue streams from timber and consumer states eager to ensure a continuing supply of timber have actively worked to undermine the environmental effectiveness of the ITTO. ${ }^{148}$

Gale argues that the organization is suffering from "agency capture" and has come to be dominated by a relatively small group of key producer and consumer states. On the producer side, Brazil, Malaysia and Indonesia, all with large timber company interests, dominate ITTO debates. On the consumer side Japan, the Netherlands, the U.K. and the U.S.A. have outsized roles. ${ }^{149}$ Any effort to understand the normative evolution of the organization must understand the interplay of interests between these two coalitions reflected in the decisionmaking framework of the ITTO. These interests are also reflected in the byzantine voting structure that has stymied environmental normative change. It does so by rewarding states that are exploiters, and disadvantages states that put in place effective conservationist measures. Deplorably, the faster a producer state cuts down its forests, the more voting power they accrue and the more a state consumes it is also accorded greater political sway.

Legro's analysis of normative robustness enables a broader understanding of the reasons why the norm of exploitation has yet to be supplanted by the norm of conservation within the ITTO. The conservationist norm fails all three prongs of his proposed test in that it is not currently specific enough to be adhered too by member-states; its durability should be considered poor since it has been violated multiple times by the majority of states; and it has a low concordance amongst member-states. It is clear that environmental protection is unlikely to succeed until several preconditions are met: a working definition of sustainability/conservation is agreed to by member-states; the ITTO structure which allows ongoing exploitation is significantly altered to allow for a greater weight being given those espousing conservationist mores; and ENGOs are given a true 'voice' at the ITTO negotiating table and allowed to be part of ongoing decisions.

The ITTO is now perceived by ENGOS as merely a lobbying group for timber interests. ${ }^{150}$ The ENGOs have thus decided that the ITTO is not the forum to attain environmental goals and have abandoned the ITTO, preferring to achieve its goals through the Forest Stewardship Council (FSC). ${ }^{151}$ The FSC, whose voting and organizational structures allows greater input from ENGOs thus offers potentially a far better chance for meaningful dialogue and global environmental normative change. ${ }^{152}$ Thus, if the ITTO cannot change in the immediate future, a new approach is needed which includes working in other forums to the exclusion of the ITTO. However, time is running out to save tropical forests for future generations, both human and non-human.

\section{References}

1. Abramovitz, Janet N, Ashley TM (1999) "Reorienting the Forest Products Economy." In State of the World 1999: A Worldwatch Institute Report on Progress Towards a Sustainable Society, edited by Linda Starke, pp. 60-77. New York: W.W. Norton \& Company, USA.

2. Anderson, Anthony B (1993) "Deforestation in Amazonia: Dynamics, Cause and Alternatives." In The Earthscan Reader in Tropical Forestry, edited by Simon Reitbergen, pp. 165-84. London: Earthscan Publications Ltd, UK.

3. Axelrod, Robert M (1997) The Complexity of Cooperation: Agent-Based Models of Competition and Collaboration, Princeton Studies in Complexity. Princeton, NJ: Princeton University Press, UK.

4. Barbier, Edward, Burgess J, Bishop J, Aylward B (1994) "Deforestation: The Role of the International Trade in Tropical Timber." In The Causes of Tropical Deforestation: The Economic and Statistical Analysis of Factors Giving Rise to the Loss of the Tropical Forests, edited by Katrina

147 Dimitrov, "Hostage to Norms: States, Institutions and Global Forest Politics," 7.

148 Young and Demko, "Improving the Effectiveness of International Environmental Governance Systems," 234.

149 Gale, "Discourse and Southeast Asian Deforestation: A Case Study of the International Tropical Timber Organization," 243.

150 Marcus Colchester, "The International Tropical Timber Organization: Kill or Cure for the Rainforests?," The Ecologist 20, no. 5 (1990): 166.

151 The Forest Stewardship Council (FSC) was created in March 1992. Its stated goal is to establish a non-governmental sustainable timber accreditation programme for all global forests. Poore, Changing Landscapes: The Development of the International Tropical Timber Organization and its Influence on Tropical Forest Management, London: Earthscan, 2003, 148. It has a unique governing structure comprising a devolved, chamber-based membership that encourages interactions between forest stakeholders and ENGOs are treated as equal partners in the endeavour. Fred P. Gale, "Public Accountability in Private Regulation: Contrasting Models of the Forest Stewardship Council (FSC) and Marine Stewardship Council" (paper presented at the Australasian Political Studies Association Conference, University of Adelaide, 2004), 15.

152 Poore, Changing Landscapes: The Development of the International Tropical Timber Organization and Its Influence on Tropical Forest Management, 148.; D. Humphreys, "Discourse as Ideology: Neoliberalism and the Limits of International Forest Policy," Forest Policy and Economics (2008), 3.; Fred P. Gale, "Public Accountability in Private Regulation: Contrasting Models of the Forest Stewardship Council (FSC) and Marine Stewardship Council" (paper presented at the Australasian Political Studies Association Conference, University of Adelaide, 2004), 15. 
Brown and David W. Pearce, pp. 271-95. London: UCL Press Limited UK.

5. Solinge BV, Tim (2008) "Eco-Crime: The Tropical Timber Trade." In Organized Crime: Culture, Markets and Policies, edited by D. Siegel and H. Nelen. New York: Springer, USA.

6. Boekle, Henning, Rittberger V, Wagner W (1999) "Norms and Foreign Policy: Constructivist Foreign Policy Theory." Tubingen Working Papers $34 \mathrm{a}$.

7. Brunnee, Jutta (1996) "A Conceptual Framework for an International Forests Convention: Customary Law and Emerging Principles in Global Forests and International Law." In Global Forests and International Law, edited by Canadian Council of International Law., pp. 41-78. London: Kluwer Law International, UK.

8. Bryner, Gary C (1997) From Promises to Performance: Achieving Global Environmental Goals. New York: W.W. Norton \& Company Inc., USA.

9. Chasek, Pamela S (2001) Earth Negotiations: Analyzing Thirty Years of Environmental Diplomacy. Tokyo ; New York: United Nations University Press, USA.

10. Chaytor, Beatrice (2001) "The Development of Global Forest Policy: Overview of Legal and Institutional Frameworks." International Institute for Environment and Development World Business Council for Sustainable Development.

11. Checkel JT (1999) "Norms, Institutions and National Identity in Contemporary Europe," International Studies Quarterly 43: 56-78.

12. Chew, Sing C (2001) World Ecological Degradation: Accumulation, Urbanization, and Deforestation 3000 B.C. - A.D. 2000. Walnut Creek, CA: AltaMira Press.

13. Cock, Robert A (2008) "Tropical Forests in the Global State System." International Affairs 84, no. 2: 315-33.

14. Colchester, Marcus (1995) "Colonizing the Rainforests: The Agents and Causes of Deforestation." In The Struggle for Land and the Fate of the Forests, edited by Marcus Colchester and Larry Lohmann, pp. 1-15. London: Zed Books, UK.

15. "The International Tropical Timber Organization: Kill or Cure for the Rainforests?" The Ecologist 20: 163-73.

16. "The International Tropical Timber Organization: Kill or Cure for the Rainforests?" In The Earthscan Reader in Tropical Forestry, edited by Simon Rietbergen. London: Earthscan Publications Ltd, 1993.

17. Cooke, Majid F (1999) The Challenge of Sustainable Forests: Forest Resource Policy in Malaysia, 1970-1995. Honolulu: University of Hawai'i Press, Malaysia.

18. Dauvergne, Peter (2001) Loggers and Degradation in the Asia-Pacific: Corporations and Environmental Management. Cambridge: Cambridge University Press, UK.

19. Shadows in the Forest: Japan and the Politics of Timber in Southeast Asia, Politics, Science, and the Environment. Cambridge, Mass.: MIT Press, 1997.

20. "The Environmental Challenge to Loggers in the Asia-Pacific: Corporate Practices in Informal Regimes on Governance." In The Business of Global Environmental Governance, edited by David L. Levy and Peter J. Newell, pp. 169-96. Cambridge, MA: MIT Press, 2004.

21. Davenport, Deborah, S, Louw (2008) Jonathan Manley, and Peter Wood. "Summary of the Forty-Fourth Session of the International Tropical Timber Council and Associated Sessions of the Four Committees: 3-8 November 2008." Earth Negotiations Bulletin 24, no. 81: 1-17.

22. de Jong, Wil, Lye Tuck-Po, Abe Ken-ichi (2003) "The Political Ecology of Tropical Forests in Southeast Asia: Historical Roots of Modern Problems." In The Political Ecology of Tropical Forests in Southeast Asia, edited by Wil de Jong, Lye Tuck-Po and Abe Ken-ichi, pp. 1-28. Melbourne: Trans Pacific Press, Australia.

23. DeSombre, Elizabeth R (2002) The Global Environment and World Politics, International Relations for the 21st Century. London: Continuum, UK.

24. Dimitrov, Radoslav S (2005) "Hostage to Norms: States, Institutions and Global Forest Politics." Global Environmental Politics 5: 1-24.
25. Douglas, James J (1983) A Re-Appraisal of Forestry Development in Developing Countries. Boston: Martinus Nijhoff Publishers, UK.

26. Drollete, Dan. 'Plague of deforestation sweeps across Southeast Asia

27. Illegal logging and unchecked economic development are taking a devastating toll on forests', theguardian.com, 21 May 2013.

28. Eckersley, Robyn (1992) Environmentalism and Political Theory : Toward an Ecocentric Approach. London: UCL Press, UK.

29. Elliott, Chris, Donovan RZ (1996) "Introduction." In Certification of Forest Products: Issues and Perspectives, edited by Virgilio M. Viana, Jamison Ervin, Richard Z. Donovan, Chris Elliott and Henry Gholz, pp. 1-10. Washington, D.C.: Island Press, USA.

30. Elliott, Lorraine M (1998) The Global Politics of the Environment. Hampshire: Macmillan, UK.

31. "European Union Statement, Annex 2: Statement in Explanation of Positions by Member Countries. ." Paper presented at the Fourth (Final) Part of the United Nations Conference for the Negotiation of a Successor Agreement to the International Tropical Timber Agreement, 1983, Geneva, Switzerland, 10-26 January 1994.

32. "Final Working Document Resulting from the Second Part of the Conference." Paper presented at the Conference for the Negotiation of a Successor Agreement to the International Tropical Timber Agreement, Geneva, Switzerland, 27 June - 1 July 2005.

33. "Final Working Document Resulting from the Third Part of the Conference." Paper presented at the Conference for the Negotiation of a Successor Agreement to the International Tropical Timber Agreement, Geneva, Switzerland, 27 June - 1 July 2005.

34. Flejzor, Lauren (2005) "Reforming the International Tropical Timber Agreement." RECIEL 14: 19-27.

35. Food and Agriculture Organization. "State of the World's Forests 2005." Food and Agriculture Organization, 2005.

36. Formal Statement by Consumer Members: International Tropical Timber Agreement 1994. 1994. (accessed 10 October, 2005).

37. Forsyth, Adrian, Miyata K (1984) Tropical Nature: Life and Death in the Rainforests of Central and South America. New York: Simon and Schuster, USA.

38. Friends of the Earth, and World Rainforest Movement (1992) "The International Tropical Timber Agreement: Conserving the Forests or Chainsaw Charter? A Critical Review of the First Five Years' Operations of the International Tropical Timber Organization." Friends of the Earth.

39. Gale, Fred P (2003) "Discourse and Southeast Asian Deforestation: A Case Study of the International Tropical Timber Organization." In The Political Ecology of Tropical Forests in Southeast Asia: Historical Perpectives, edited by Wil de Jong, Lye Tuck-Po and Abe Ken-ichi, pp. 236-64. Melbourne: Trans Pacific Press, Australia.

40. "Public Accountability in Private Regulation: Contrasting Models of the Forest Stewardship Council (FSC) and Marine Stewardship Council." Paper presented at the Australasian Political Studies Association Conference, University of Adelaide 2004.

41. "The Mysterious Case of the Disappearing Environmentalists: The International Tropical Timber Organization." Capitalism, Nature, Socialism 7, no. 3 (1996): pp. 103-17.

42. The Tropical Timber Trade Regime, International Political Economy Series. New York: St. Martin's Press, 1998.

43. "Public Accountability in Private Regulation: Contrasting Models of the Forest Stewardship Council (FSC) and Marine Stewardship Council" (paper presented at the Australasian Political Studies Association Conference, University of Adelaide, 2004).

44. Smith W (1980) "The Rights of Non-Humans and Intrinsic Values." In Environmental Philosophy, edited by D.S. Mannison, M.A. McRobbie and R. Routley, pp. 30-47. Canberra: Department of Philosophy, Research School of Social Science, Australian National University, Australia.

45. Goodland, Robert (1990) The Race to Save the Tropics: Ecology and Economics for a Sustainable Future. Washington D.C.: Island Press, USA. 
46. Grainger, Alan (1980) "The State of the World's Tropical Rainforests." Ecologist 10: 6-54.

47. Guppy, Nicholas (1996) "International Governance and Regimes Dealing with Land Resources from the Perspective of the North." In Global Environmental Change and International Governance, edited by Oran R. Young, George J. Demko and Kilaparti Ramakrishna, pp. 136-65. Hanover, N.H.: University Press of New England, UK.

48. Hay, Peter (2002) Main Currents in Western Environmental Thought. Sydney: UNSW Press, Australia.

49. Head, Susan, Heinzman R (1990) Lessons of the Rainforest. San Francisco: Sierra Club Books for Children.

50. High Stakes: The Need to Control Transnational Logging Companies: A Malaysian Case Study - Part 2b: Politics, Law and the Logging Industry. 1998. In, World Rainforest Movement \& Forests Monitor (accessed 11 May, 2004).

51. Humphreys D (1996) "Hegemonic Ideology and the International Tropical Timber Organization." In The Environment and International Relations, edited by John Vogler and Mark F. Imber, pp. 215-33. London: Routledge, UK.

52. Humphreys, David (1999) "The Evolving Forests Regime." Global Environmental Politics 9: 251-54.

53. "Life Protective or Carcinogenic Challenge? Global Forests Governance under Advanced Capitalism." Global Environmental Politics 3, no. 2 (2003).

54. "Redefining the Issues: NGO Influence on International Forest Negotiations." Global Environmental Politics 4, no. 2 (2004): pp. 51-74.

55. "Ngo Influence on International Policy on Forest Conservation and the Trade in Forest Products." In Ngo Diplomacy: The Influence of Nongovernmental Organisations in International Environmental Negotiations, edited by Michele M. Betsill and Elisabeth Corell Cambridge, M.A.: MIT Press, 2008pp. 149-206.

56. International Tropical Timber Organisation"International Tropical Timber Agreement 1983."

57. 1994. International Tropical Timber Agreement. In,United Nations Conference on Trade and Development, (accessed 9 January, 2006).

58. "Technical Series 5: ITTO Technical Guidelines for the Sustainable Management of Tropical Resources." Yokohama, 1990.

59. "ITTO Yokohama Action Plan 2002-2006." In ITTO Policy Development Series No. 11: International Tropical Timber Organization, 2002.

60. "Annual Review and Assessment of the World Timber Situation." 2003.

61. International Tropical Timber Agreement 2006. In,United Nations Conference on Trade and Development, (accessed 15 March, 2006).

62. About ITTO. (accessed 15 January, 2006).

63. "International Tropical Timber Agreement 2006." United Nations Conference on Trade and Development.

64. "International Tropical Timber Agreement, 2006." United Nations Conference on Trade and Development, 25 April. 2007

65. "News Release: Legality Shapes as New Certification Flashpoint." 23 December, 2008.

66. "Decision 4(XLIV) the Itto Action Plan 2008-2011 Transitional Period." 20 January, 2009.

67. "Decision 7(XLIV) Entry into Force of the International Tropical Timber Agreement, 2006." 20 January, 2009.

68. "U.S.\$8.6 Million in New Funds for Tropical Forests." 21 January, 2009

69. "ITTO Strategic Action Plan 2013-2018."

70. Kahn, James, Judith MD (1994) "International Debt and Deforestation." In The Causes of Tropical Deforestation: The Economic and Statistical Analysis of Factors Giving Rise to the Loss of the Tropical Forests edited by Katrina Brown and David W. Pearce, pp. 57-67. London: UCL Press Limited, UK.

71. Kasimbazi, Emmanuel (1996) "Sustainable Development in International Tropical Timber Agreements." Journal of Energy \& Natural Resources Law 14: 137-60.
72. Kibel, Stanton (1999) The Earth on Trial: Environmental Law on the International Stage.

73. Kolk, Ans (1996) Forests in International Environmental Politics : International Organisations, NGOs and the Brazilian Amazon. Utrecht, Netherlands: International Books, Australia.

74. Krasner, Stephen D (1983) International Regimes, Cornell Studies in Political Economy. (Ithaca: Cornell University Press, 1983).

75. Laarman, Jan G (1988) "Export of Tropical Hardwoods in the Twentieth Century." In World Deforestation in the Twentieth Century, edited by John F. Richards and Richard P. Tucker, pp. 147-63. Durham: Duke University Press.

76. Legro JW (1997) "Which Norms Matter? Revisiting the 'Failure' of Internationalism." International Organization 51: 31-63.

77. London Environmental Economics Centre (1993) "The Economic Linkages between the International Trade in Tropical Timber and the Sustainable Management of Tropical Forests." London: International Tropical Timber Organisation.

78. Max, Arthur (2011) 'Malaysia deforestation is three times faster than the rest of Asia combined', February 1st, 2011.

79. Miettinen, Jukka, Chenghua S, Chin LS (2011) 'Deforestation rates in insular Southeast Asia between 2000 and 2010', Global Change Biology, (2011) 17, 2261-2270.

80. Mukherjee,Krittivas (2008)‘Asia must reverse massive deforestation: U.N.', March 27, 2008.

81. Myers, Norman (1989) "The Future of Forests." In The Fragile Environment: The Darwin College Lectures edited by Laurie Friday and Ronald Laskey, pp. 22-40. Cambridge: Cambridge University Press, UK.

82. New Forest Treaty Agreed. 2006. In,International Tropical Timber Organisation.

83. Ngau, Harrison, Apoi JT, Ling CY (1987) "Malaysian Timber: Exploitation for Whom?" In Forest Resource Crisis in the Third World Penang: Sahabat Alam Malaysia, Malaysia.

84. Oelschlaeger, Max (1993) Idea of Wilderness : From Prehistory to the Age of Ecology. New ed. New Haven: Yale University Press, Australia.

85. U.N. General Assembly (1803) Permanent Sovereignty over Natural Resources Resolution (XVII).

86. Poore, Duncan (2003) Changing Landscapes: The Development of the International Tropical Timber Organization and its Influence on Tropical Forest Management. London ; Sterling, VA: Earthscan Publications, UK.

87. Poore, Duncan, Burgess P, Palmer J, Rietbergen S, Synnott T (1989) No Timber without Trees: Sustainability in the Tropical Forest. London: Earthscan Publication Ltd, UK.

88. Poore, Duncan, Chiew TH (2000) "Review of Progress Towards the Year 2000 Objective." International Tropical Timber Council.

89. Porter, Gareth, Brown JW (1991) Global Environmental Politics. Boulder: Westview Press, Australia.

90. Raymond, Eric (2002) "Road Development in Northwestern Brazil: Economic Integration against Ethnic and Ecological Degradation." International Affairs Review 11 88-99.

91. Risse, Thomas (2000), "'Lets Argue!": Communicative Action in World Politics." International Organization 54: 1-39.

92. Rowlands, Ian H (2001) "Classical Theories of International Relations," in International Relations and Global Climate Change, ed. U. Luterbacher and D.F. Sprinz, 55.

93. Rush, James (1991) The Last Tree: Reclaiming the Environment in Tropical Asia. Oxford: Westview Press, UK.

94. Secrett, Charles (1987) "How European Transnational Corporations and Government Control and Exploit 3rd World Resources." In Forest Resource Crisis in the Third World, pp. 233-49. Penang: Sahabat Alam Malaysia, Malaysia.

95. Smouts, Claude M (2003) Tropical Forests, International Jungle: The Underside of Global Ecopolitics. New York, N.Y.: Palgrave Macmillan, USA. 
Citation: Nagtzaam G (2014) Into the Woods: Analyzing Normative Evolution and the International Tropical Timber Organization. Arts Social Sci J 5: 85. doi:10.4172/2151-6200.100085

Page 17 of 17

96. Switzer, Vaughn J (2004) Environmental Politics : Domestic and Global Dimensions. 4th ed. Belmont, CA: Thomson/Wadsworth, UK.

97. Tarlock, Dan A (1997) "Exclusive Sovereignty Versus Sustainable Development of a Shared Resource: The Dilemma of Latin American Rainforest Management." Texas International Law Journal 32: 37-66.

98. Taylor, Paul W (1989) Respect for Nature: A Theory of Environmental Ethics. Princeton, N.J.: Princeton University Press, UK.

99. Thomas, Caroline (1992) The Environment in International Relations. London: Royal Institute of International Affairs, UK.

100. Thompson, Herb (2003) "The Ecological-Economics of Non-Sustainable Development: Logging Tropical Forests in Southeast Asia and the Pacific." In The Political Ecology of Tropical Forests in Southeast Asia: Historical Perpectives, edited by Lye Tuck-Po, Wil de Jong and Abe Kenichi, pp. 200-35. Kyoto: Kyoto University Press, UK.

101. United Nations Environment Programme (1990) "Environmental Data Report." New York: Oxford Press, USA.

102. Utting, Peter (1993) Trees, People and Power: Social Dimensions of Deforestation and Forest Protection in Central Ameerica. London: Earthscan Publications Ltds, UK.

103. VanderZwaag, David, MacKinlay DM (1996) "Towards a Global Forest Convention: Getting out of the Woods and Barking up the Right Tree."
In Global Forests and International Environmental Law, edited by Canadian Council of International Law., pp. 1-41. London: Kluwer Law International, UK.

104. Wertheimer, Alan (1996) Exploitation. Princeton, N.J.: Princeton University Press, USA.

105. Wood, Peter (2004) Soft Law, Hard Law and the Development of an International Forest Convention. (accessed 14 May, 2005).

106. "Working Document Resulting from the First Session." Paper presented at the Conference for the Negotiation of a Successor Agreement to the International Tropical Timber Agreement, Geneva, Switzerland, 26-30 July 2004.

107. World Rainforest Movement. Rainforest Destruction: Causes, Effects and False Solutions. Penang: World Rainforest Movement, 1990.

108. Young, Oran R, Demko GJ (1996) "Improving the Effectiveness of International Environmental Governance Systems." In Global Environmental Change and International Governance, edited by Oran Young R, George J (1996) Demko and Kilaparti Ramakrishna, pp. 229-47. Hanover: University Press of New England, UK. 